\title{
41719
}

\section{Corpos colonizados: Recursos com paisagem em fundo. Uma agenda de pesquisa}

\author{
António Fernando Cascais \& Mariana Gomes da Costa
}

\section{Resumo:}

A fotografia dos corpos colonizados visava registar os estigmas raciais que os caraterizavam à luz da antropobiologia portuguesa decalcada da matriz norte-europeia, mas revista e adaptada à exploração colonial. O estudo concentrou-se no cálculo da inteligência no sentido de avaliar da sua assimilabilidade, na mensuração antropométrica e ergográfica com o fim do aproveitamento de mão-de-obra e na deteção de patologias que a podiam comprometer ou ser transmissíveis aos colonizadores. As populações colonizadas foram integradas como material humano no quadro geral do levantamento e exploração de recursos naturais, flora, fauna, minérios, culturas agrícolas, de tal modo que a serviçalidade dos seus corpos funcionou como mediadora da relação do colonizador com a paisagem natural dos territórios ocupados. Integral ao processo de racialização indispensável ao sucesso da empresa colonizadora, o registo fotográfico não só constituiu um documento do arquivo colonial português, como um instrumento epistemopolítico do dolo infligido pela colonização às suas vítimas históricas, desde logo como operador da construção do Outro racial exotizado que, ao definir o limiar em que o primata devém humano, traça por aí mesmo a fronteira inultrapassável pelas raças inferiores, patente nos estigmas físicos e psíquicos que indiciam a sua ancestralidade simiesca. Esta indiciologia fotográfica foi fundamental para a justificação e legitimação do "fardo do homem branco" luso, traduzido nos termos próprios da sua missão civilizadora, assumida como desígnio histórico secular que, a partir do diferendo do "mapa cor-de-rosa" e do empenhamento na Primeira Guerra Mundial, se alcandorou a pugna pela salvaguarda da identidade e da independência nacional.

Palavras-chave: colonização; antropometria; fotografia; corpo; raça. 


\begin{abstract}
:
The photography of the colonized bodies purported to record the racial stigmata that characterized them under the light of the Portuguese Anthropobiology moulded after the northern-european paradigm, but duly revised and adapted from the standpoint of the Portuguese colonial exploration. The study focused on the measurement of indigenous intelligence in order to evaluate their susceptibility to assimilation, on the anthropometric and ergographic evaluation in order to make good use of labour force and on the detection of pathologies that might jeopardize it or be transmissible to settlers. The colonized populations were integrated as human material in the overall framework of survey of natural resources, flora, fauna, ore, farming assets, in such way that their bodily resourcefulness mediated the relationship between the settler and the natural environment of the occupied territories. Fully integral to the racialization process that was instrumental to the success of the colonizing endeavour, the photographic recording isn't merely a document in the Portuguese Colonial Archive, but above all na epistemopolitical tool of the harm that was inflicted by the colonization to its historical victims, first and foremost as an operator of the construction of the racialized exotic Other that, while defining the thresh-old beyond which the primate becomes human, also delineates the boundary that cannot be crossed by the inferior races, made visible by the physical and behavioural stigmata of their simian ancestry. Such photographic indiciology was instrumental in the justifying and legitimazing of the Portuguese "white man's burden", translated into the terms of our own civilizing mission that was taken up as an ages-old historical design, one that, in the aftermath of the "Pink Map" dispute and the engagement in World War I, rose to the level of a struggle for the safeguarding of national identity and independence.
\end{abstract}

Keywords: colonization; anthropometry; photography; body; race.

A origem longínqua do imaginário colonial(ista) português que enformou o mito da missão colonizadora nacional encontramo-la em dois tropos matriciais geminados, já detetáveis em documento tão originário como é a Carta de Pero Vaz de Caminha, mas que ainda cristalizam no romantismo nacionalista de oitocentos e no republicanismo e que ressoam até aos últimos dias das guerras coloniais. $O$ tropo da dádiva de Deus que transparece no "achamento" de uma terra que desde tempos imemoriais aguardava ser descoberta e usufruída como "nossa" com todos os seus tesouros e o tropo do dom de que o mesmo Deus faz graça aos descobridores pela pura virtude do seu merecimento. Trata-se de duas figuras, uma extrativa, outra da excecionalidade, que, devidamente secularizadas e reformuladas nos termos, respetivamente, da economia-mundo capitalista e da superioridade civilizacional e étnica, se mantêm mais ou menos 
subterraneamente com a emergência da ciência moderna, após a revolução do evolucionismo darwiniano, da antropobiologia e da higiene racial, por sua vez contemporâneas da fase imperialista de ocupação colonial efetiva.

\section{A antropologia portuguesa e o colonialismo}

Com efeito, a antropobiologia higienista portuguesa inseriu-se plenamente nas tendências científicas internacionais, desde os momentos iniciais do acolhimento, ainda no século XIX - e sem pretendermos confundi-los numa amálgama indistinta - do positivismo, do darwinismo-social, do degeneracionismo moreliano e lombrosiano e do racismo anti-semita (Cleminson, 2011: 143; Madureira, 2003: 291; Pereira, 2001: 244311, 479-528; Pimentel \& Ninhos, 2013: 209-214). Assim foi até ao virar das décadas de 1920 para 1930, quando o pensamento eugénico, em que todos eles vêm desaguar, se encontrava já difundido em amplas áreas da medicina, da biologia e da antropologia portuguesas (Cleminson, 2011: 145). Esse acolhimento teve por eixo o ensino e a investigação universitária, institucionalizados em primeiro lugar com a chamada Escola de Antropologia de Coimbra, pelo menos desde o estabelecimento do ensino da Antropologia, no já distante ano de 1885, data da criação do Curso de Antropologia, Paleontologia Humana e Arqueologia Pré-histórica (Gago, 2009: 65; Matos, 2012: 5859; Tamagnini, 1947: 5; Tamagnini e Serra, 1942: 4-12), e com o Museu e o Laboratório Antropológico a ele adstritos, por iniciativa de Bernardino Machado, futuro Presidente da República (1915-1917 e 1925-1926). A partir de 1907 e até 1950, ele foi chefiado por Eusébio Tamagnini, no decurso de cuja direção mudou o nome para Instituto de Antropologia da Universidade de Coimbra e se operou a vinculação da "Eugenética" à Antropologia (Tamagnini e Serra, 1942: 13).

Com a reforma do Ensino Superior de 1911, o ensino da Antropologia alargou-se às Faculdades de Ciências das Universidades de Lisboa e do Porto, foi introduzida a cadeira de Etnologia nas Faculdades de Letras, ao mesmo tempo que, nas Faculdades de Medicina de Lisboa e do Porto, se destacaram os Institutos de Anatomia, o primeiro dirigido por Henrique de Vilhena, que a partir de 1912 passou a publicar o Arquivo de Anatomia e Antropologia, e o segundo dirigido por J. A. Pires de Lima, onde se publicava a revista $O$ Instituto de Anatomia. Em conjunto com a Sociedade Portuguesa de Antropologia e Etnologia, fundada no Porto em 1918, estes institutos organizaram o XV Congresso Internacional de Antropologia e Arqueologia Pré-histórica e a IV. ${ }^{\underline{a}}$ sessão do Instituto Internacional de Antropologia, com parte das suas sessões em 1930 no Porto, e o I Congresso Nacional de Antropologia Colonial, que teve lugar em 1934 (Matos, 2012: 57). 
Pela sua parte, a Sociedade Portuguesa de Antropologia e Etnologia (SPAE), de que António Augusto Mendes Correia foi o principal impulsionador, publicou os Trabalhos da Sociedade Portuguesa de Antropologia e Etnologia, que, a partir de 1945 passaram a chamar-se Trabalhos de Antropologia e Etnologia. Os Estatutos iniciais da SPAE estabeleciam que era sua missão estimular e cultivar em Portugal o estudo dos métodos antropológicos, da antropologia zoológica, antropologia étnica, antropologia e arqueologia pré-históricas, psicologia experimental, etnografia, e dos ramos científicos seus derivados ou aplicados, como as antropologias militar, pedagógica, clínica, criminal e judiciária. Entre as muitas atividades suscetíveis de pôr em prática aqueles objetivos, incluíam-se a organização de coleções antropológicas, arqueológicas e etnográficas, a divulgação dos métodos antropológicos sobretudo entre médicos, professores, viajantes e coloniais, a propaganda das vantagens da antropologia escolar, e bem assim dos serviços de identificação antropológica, particularmente como elemento de polícia científica, para além da intensificação e extensão do ensino das ciências antropológicas em Portugal e da investigação de campo, com inquéritos e missões científicas, tanto no país como nas colónias. A investigação antropológica e etnológica nas então colónias portuguesas nasce pois geminada com a mesma pesquisa na metrópole e, por essa via, vizinha de outras áreas disciplinares como a criminologia, a medicina legal e a psiquiatria forense. Patrícia Ferraz de Matos esclarece: "Uma alteração relevante dos estatutos de 1924 ocorreu na alínea g) do Art.. 1.ำ em que passou a estar escrito «metrópole», em vez de país, e «ultramar», em vez de colónias" (Matos, 2012: 69), o que só muito mais tarde viria a ser adotado na nomenclatura política e administrativa do regime.

A rivalidade existente entre a escola portuense e a escola coimbrã (Matos, 2012: 60-61) passou muitíssimo menos por aquilo que podemos chamar "epistemopolíticas" claramente diferenciadas, pois as bases concetuais e metodológicas eram comuns, para além das afinidades políticas e o engajamento doutrinário no regime do Estado Novo, do que pelos campos de investigação aplicada. A investigação antropobiológica colonial foi essencialmente desenvolvida pelos portuenses, com Mendes Correia como figura tutelar impulsionadora das missões antropobiológias às então colónias de Angola, Guiné e Moçambique. Tendo-se prolongado da década de 1930 à de 1950, elas transpuseram a barreira constituída pelo imediato pós-Segunda Guerra Mundial, que assistiu ao descrédito internacional da ciência racial, não parece ter tido repercussão significativa nos meios científicos portugueses, o que, contextualizado pelo crescente isolamento do país no concerto das nações, explicaria em boa parte "um certo anacronismo teórico e metodológico, nos trabalhos produzidos, o que, de resto, vigorou 
em grande parte do século XX em Portugal. Além disso, a antropologia portuguesa era marginal no contexto internacional" (Matos, 2012: 89).

Por outro lado, já não acompanhamos Patrícia Ferraz de Matos quando considera que a a antropologia portuguesa se encontra numa situação intermédia nas duas tradições de desenvolvimento da ciência antropológica desde finais do século XIX, a tendência que, na terminologia de George Stocking, foi chamada de "construção do império" (Völkerkunde), prevalecente nos países que possuíam grandes impérios coloniais (designadamente Grã-Bretanha e França), e a tendência de "construção da nação" (Volkskunde), ligado à construção da "identidade nacional" (nos países europeus de periferia ou semiperiferia que não tinham colónias e lutavam ainda pela sua autonomia). Com efeito, e à luz da ideia, que remonta a Eduardo Lourenço, segundo a qual a consciência imperial nunca se consolidou ao ponto de sobrelevar a arreigada consciência da identidade nacional, o que se nos oferece dizer, porventura mais finamente, é que a nossa antropologia de "construção do império" sempre se subordinou à "construção da nação" e que essa subordinação se operou em função da tese lusotropicalista da excecionalidade da benevolência do colonialismo português, cuja receção se intensificou numa época, pós-Segunda Guerra Mundial, em que este já se debatia, e em desespero de causa, com a contestação mundial generalizada ao seu paradigma epistemopolítico. A reformulação da ideia de império colonial, de resto nunca verdadeiramente consolidada, pela ideia de uma nação pluricontinental e multiracial "do Minho a Timor" constituiu o derradeiro avatar dessa excecionalidade, que, no pósSegunda Guerra Mundial, pressupunha, de maneira informulada e fantasmática, a própria sobrevivência da nação. Por outro lado - e esta é uma queixa recorrente entre os protagonistas das missões coloniais - o país nunca teve condições para canalizar para elas os avultados fundos de que dispunham as grandes potências coloniais com as quais nunca pudemos realmente competir - o que reforça a ideia de excecionalidade por compensação mítica que nos torna "incomparáveis" com outros colonialismos.

Também não podemos seguir Patrícia Ferraz de Matos nas suas críticas à obra do italiano Donato Gallo, para quem a antropologia portuguesa serviu desde os seus primórdios o projeto colonial. Sustentando que a antropologia e a exploração colonial se desenvolveram paralelamente como duas áreas estanques, Matos recorre à justificação de que a antropologia não se interessou apenas pelas populações coloniais, mas por outros grupos humanos como os doentes mentais, físicos, ou com anomalias diversas, prostitutas, delinquentes, criminosos, populações rurais e piscatórias, entre outros (Matos, 2012: 223). Em igual direção parece ir Ana Cristina Martins, ao afirmar que a entrada da antropologia física no plano colonial a partir da década de 1930 (contrastando com o alheamento institucional e governamental em relação às 
expedições científicas de finais do século anterior) ficou a dever-se à insistência de personalidades ligadas à cultura e à Universidade - entre as quais avultam as figuras de Mendes Correia ou de Tamagnini -, as quais teriam conseguido demonstrar a sua premência para a construção da ideia de uma nação não apenas pluricontinental como multirracial (Martins, 2014: 125).

Refira-se ainda a posição de Madureira, que traça uma vincada separação e uma relação exclusiva entre os usos científico e estatal da antropometria, fazendo mesmo depender a passagem desta a ciência do Estado do seu esvaziamento teórico, reduzido o conhecimento a uma prática burocrática utilitária (Madureira, 2003: 294). Justamente, segundo Madureira, teria sido a quebra do vínculo entre a antropologia e a criminologia aquilo que permitiu aos antropometristas, agrupados em torno de Mendes Correia e da Escola de Antropologia do Porto, virarem o seu olhar para outros campos, vide a antropologia física dos indígenas (Madureira, 2003: 299). Não podemos concordar com esta separação entre as esferas e os tempos da ciência e do controlo estatal. Bem pelo contrário - e é isso que está também em causa no pensamento de Ferraz de Matos e de Ana Cristina Martins -, trata-se de entendê-los estritamente ligados e baseando-se mutuamente em todos os momentos, segundo o nexo forte entre poder e saber conforme entendido por Foucault, cuja obra mostrou bem como todo e qualquer saber só pode ser fixado à custa de um conjunto de mecanismos coercivos e, reciprocamente, todo o poder depende de conteúdos de saber que o validam e garantem (Foucault, 1980: 49).

Do exposto, em nosso entender, resulta que a antropologia - e designadamente a antropobiologia portuguesa - não só foi coextensiva ao projeto de ocupação e exploração colonialista, como lhe foi congenial: ao contrário do que sustenta Matos, eles não se limitaram a desenvolver-se paralelamente como duas áreas estanques. Recorrer à justificação de que a antropologia não se interessou apenas pelas populações coloniais, mas por outros grupos humanos como os doentes mentais, físicos, ou com anomalias diversas, prostitutas, delinquentes, criminosos, populações rurais e piscatórias, entre outros, é cair no equívoco de ignorar a solidariedade profunda entre a vertente da ciência racial que trata da ortogénese da raça branca, colonizadora que há que depurar e regenerar de todas as suas degenerescências, e a diferenciação exclusora das raças inferiores dos povos colonizados. Com efeito, o empreendimento colonial e o projeto antropológico encontram-se soldados pelo problema higiénico-racial da mestiçagem, que os antropólogos portugueses como Mendes Correia consideram não se pôr na metrópole, para constituir, ao invés, uma questão candente nas colónias cujos povos era mister civilizar. 


\section{O estabelecimento de uma antropobiologia colonial: uma demarcação}

Por outro lado, ainda, é a partir deste ponto que a antropologia nacional começa a demarcar-se da antropobiologia germânica que se estava a nazificar progressivamente, centrando-se, ela sim, no problema da miscigenação, que era a questão magna para os pangermanistas que faziam a apologia científica da superioridade da raça ariana. Isto acaba por revelar a suscetibilidade dos antropólogos nacionais ante aquilo que consideram ser o preconceito e o enviesamento étnico germânico - que colocava os latinos e sul-europeus na embaraçosa posição de racialmente impuros tão-só para o transferirem e reformularem em relação aos povos por si colonizados, sem enxergarem que praticam em relação a estes um racismo homólogo daquele praticado pelos alemães em relação a nós. Em resposta a estes, na sua Introdução à Antropobiologia, Mendes Correia procura, por um lado, provar a individualização do sangue português, procurando igualmente indícios físicos da nossa antiguidade e pureza étnicas (patentes, por exemplo, num índice cefálico reduzido) e expressando o desejo de encontrar uma base biológica (endocrínica) para o modo de ser português (Correia, 1933a: 40, 73-74). Contrapõe-lhes, por outro lado, que a miscigenação não é diluidora biologicamente, mas que é indesejável no plano político e social, também pelo abastardamento civilizacional a que daria azo. É, aliás, essa miscigenação que impede Mendes Correia, no extenso e ricamente ilustrado Raças do Império (1943), de concluir pela impossibilidade de uma homogeneidade racial do império - tendo o cuidado de, também aqui, deixar bem clara a superioridade da raça branca (“leucoderme", na terminologia da época), tanto fisiológica como psicológica, face à negra (“melanoderme”) - e a definir este império como "multidão em que tamanha diversidade não impede uma unidade essencial de aspirações e interêsses, uma solidariedade fraterna, a existência duma ampla e perfeita comunidade nacional, baseada simultâneamente na história, na política, num sentimento profundo de simpatia e compreensão universalista" (Correia, 1943: 603604).

Este afastamento culminou com a deriva por que passou o movimento eugenista português, no qual os antropobiólogos participaram entusiástica e maciçamente, desde a criação da Sociedade Portuguesa de Estudos Eugénicos (Pereira, 2001: 484; Pimentel e Ninhos, 2013: 214-217; Santos, 2005: 168), por ocasião das comemorações oficiais do quarto centenário da Universidade de Coimbra, no decurso das quais foi atribuído o doutoramento honoris causa a Eugen Fischer (Gago, 2009: 70-71; Matos, 2012: 216217; Pimentel, 1998; Pimentel e Ninhos, 2013: 217; Torgal, 1999: 131, 146).

Eugen Fischer era um dos mais eminentes cientistas germânicos, mundialmente renomado e como tal citado por Mendes Correia (1933a: 17), como autor de Die 
Rehoboter Bastards und das Bastardierungproblem beim Menschen ${ }^{1}$ (Jena, Verlag von Gustav Fischer, 1913), tratado tido por seminal sobre a miscigenação racial na então colónia alemã do Sudoeste Africano, atual Namíbia. Na verdade, Eugen Fischer forma com Erwin Baur e Fritz Lenz a tríade de autores que se considera estabelecerem as orientações teóricas basilares da higiene racial, cujos volumes se encontram todos na Biblioteca e Museu Antropológico: Erbpathologie² (Munique e Berlim, J. F. Lehmanns Verlag, 5 ${ }^{\text {a }}$ edição revista e aumentada), Menschliche Erblehre ${ }^{3}$ (1ํㅡ volume de Menschliche Erblehre und Rassenhygiene ${ }^{4}$, Munique, J. F. Lehmanns Verlag, 1936, 4ª edição) e, exclusivamente da autoria de Lenz, Menschliche Auslese und Rassenhygiene $^{5}$ ( $2^{\circ}$ volume de Grundiss der Menschlichen Erblichkeitlehre und Rassenhygiene $^{6}$, obra coletiva de Erwin Baur, Eugen Fischer e Fritz Lenz, Munique, J. F. Lehmanns Verlag, 1923). Fischer era diretor do Kaiser Wilhelm Institut für Anthropologie, Menschliche Erblehre und Eugenik (Instituto Kaiser Wilhelm de Antropologia, Genética Humana e Eugenia) de Berlim-Dahlem, que mantinha intercâmbio de publicações com a Sociedade Portuguesa de Antropologia e Etnologia e contactos com antropólogos portugueses que a historiografia alemã do pós-Segunda Guerra Mundial haveria de confirmar (Gago, 2009: 70-71).

A higiene racial era a primeira prioridade de investigação daquela e de outras duas prestigiadas instituições que a partir de 1948 mudariam o nome para Institutos Max Planck, o então Kaiser Wilhelm Institut für Psychiatrie (Instituto Kaiser Wilhelm de Psiquiatria) de Munique, dirigido por Ernst Rüdin, um dos principais arquitectos das leis de esterilização, e o Institut für Erbbiologie und Rassen-Hygiene (Instituto de Biologia Hereditária e Higiene Racial) da Universidade de Frankfurt, dirigido por Otmar Freiherr von Verschuer, supervisor das pesquisas de Joseph Mengele em Auschwitz e especialista de reputação internacional no estudo sobre gémeos, que sucederia a Fischer em Berlim-Dahlem após a reforma deste (Cascais, 2014: 164-165).

À comissão organizadora da Sociedade Portuguesa de Estudos Eugénicos presidiu Tamagnini, em Coimbra, tendo ficado Mendes Correia à frente da secção do Porto, e Henrique de Vilhena à frente da de Lisboa (Correia, 1933: 161), secretariados, respetivamente, por Alfredo de Ataíde e por Vítor Fontes. No entanto, nota Richard

\footnotetext{
${ }^{1}$ Os bastardos de Rehobot e o problema da mestiçagem humana (tradução livre dos autores; Rehobot é uma localidade da atual Namíbia).

${ }^{2}$ Patologia hereditária ou Heredopatologia (tradução livre dos autores).

3 Teoria da Hereditariedade Humana (tradução livre dos autores).

4 Teoria da Hereditariedade Humana e Higiene Racial (tradução livre dos autores).

${ }^{5}$ Seleção Humana e Higiene Racial (tradução livre dos autores).

${ }^{6}$ Fundamentos de Doutrina da Hereditariedade Humana e Higiene Racial (tradução livre dos autores).
} 
Cleminson, "já então o regime de Salazar tinha tornado claro que tipo de eugenia, se é que algum, haveria de ser sancionado pelo estado" (Cleminson, 2011: 145). Com efeito, embora autores portugueses continuassem a colaborar regularmente com a imprensa científica e as instituições alemãs já completamente nazificadas através do processo da Gleichschaltung - "sincronização", "alinhamento" ou "compaginação" com a ideologia "biologisch" do regime e o Führerprinzip - posto em prática de 1933 a 1937, os antropólogos portugueses acompanharam o sentimento sul-europeu de que a eugenia nazi é guiada por preocupações que, acima de tudo, respondem a um preconceito interesseiro, auto-convencido, narcísico e etnocêntrico, em exclusivo proveito dos alemães e no qual os não-alemães não se podem reconhecer porque the pressentem os prejuízos para si próprios. Facilmente se pode depreender que este é o motivo principal que sustenta a dezautorisação da "precária base científica" da eugenia nazi, nada lisonjeira relativamente aos europeus do sul que, por outro lado, se esforçavam por emular os alemães no plano da sofisticação científica (Matos, 2012: 217; Gago, 2009: 69-70).

O crescente distanciamento dos eugenistas do Sul da Europa relativamente à eugenia do Norte levou à criação da Federação das Sociedades Latinas de Eugénica, de cuja primeira reunião em Agosto de 1937 em Paris (Matos, 2012: 217; Cleminson, 2011: 137) Almerindo Lessa dá conta, por lá ter estado presente (Pimentel \& Ninhos, 2013: 224). Dizia ele que os latinos podiam ver melhor que os nórdicos problemas como os das migrações, das miscigenações e das mestiçagens, num ambiente porventura mais favorável, com uma atenção especial ao sentimento de raça e das nacionalidades particulares, etc., reputados de sentimentos e interesses com acentos particulares na Europa do Sul:

a tolerância com que nesta outra Europa se vêem as questões de raça permite que os efeitos qualitativos e quantitativos do crescimento duma delas possam ser estudados sine irae et jocundo no seio do seu areópago eugénico, pois nenhum dos associados compreenderá ou admitirá que uma raça possa ser superior às outras per ogni tempo e per ogni luogo, ou que todas as raças sejam, por igual modo, intelectualmente iguais (Lessa, 1938: 176).

Simplificando, foi deste modo que a ideia de raça se "desbiologizou" em parte na Europa do Sul, para se "culturalizar", diferenciando-se hierarquicamente as raças sobretudo em função da sua capacidade de produzir cultura, o que se coadunava com, e protegia, os projetos coloniais de países como a França, a Itália e Portugal. Estava preparado o terreno para as missões de investigação colonial, no mesmo gesto com que, na metrópole, se faziam sentir as condicionantes económicas e societárias dos flagelos sociais ainda largamente prevalecentes num país pobre e atrasado como Portugal - 
alcoolismo, tuberculose, sífilis - a cujo combate havia que dar prioridade numa sociedade ajoujada pelas carências económicas, a iliteracia, a promiscuidade, as más condições de vida e as carências de toda a espécie. A defesa do ponto de vista da causalidade hereditária era deixada aos cientistas de países como a Alemanha, que já tinha em grande medida resolvido tais questões sócio-económicas e as podia agora abordar no plano estritamente biomédico de uma higiene racial, quando, entre nós, seria sobretudo de profilaxia e higiene pública que se tratava. Mais do que a tentativa de um apuramento biológico da nação ou de uma depuração genética, estava em causa um programa de higienismo físico e mental, caracterizado pelo controlo dos casamentos ou pelo combate à reprodução mórbida, especialmente advogado este na psiquiatria de Sena, Júlio de Matos ou Magalhães Lemos (Madureira, 2003: 290-291; Pereira, 2001; Proctor, 1988). Assim, o fator determinante que viria a condicionar a receção nacional da eugenia germânica seria a existência de um império colonial e as preocupações e desígnios daí resultantes. Foram estes que enformaram os nossos próprios narcisismo etnocêntrico, racismo científico e auto-convencimento nacionalista que filtram os seus congéneres alemães em nosso interesseiro proveito: Como sumariza Maria do Mar Gago: "É possível mostrar como o regime fascista português respondeu a este contexto internacional e, ao fazê-lo, o colonialismo surge como a questão central das iniciativas políticas eugénicas em Portugal" (Gago, 2009: 68).

\section{A antropobiologia colonial: teoria e prática}

Dois eventos absolutamente decisivos, revelando a solidariedade de fundo entre a higiene racial nacional e a antropobiologia colonial marcaram igualmente o impulso originário das missões de investigação às colónias: o I Congresso Nacional de Antropologia Colonial, em 1934, e o Congresso Nacional de Ciências da População, em 1940. Do I Congresso Nacional de Antropologia Colonial, organizado no Porto por Eusébio Tamagnini e Mendes Correia de 22 a 26 de Setembro de 1934, diz Gonçalo Duro dos Santos que:

É neste congresso que se definem (...) as linhas gerais de uma antropologia naturalista colonial com o objectivo de promover a recolha de dados antropométricos e serológicos nas várias colónias portuguesas visando a elaboração de mapas etnológicos capazes de assistirem a administração colonial na racionalização da exploração do trabalho colonial (Santos, 2005: 168).

No Congresso, Tamagnini profere uma conferência sobre "Os problemas da mestiçagem" que marca emblematicamente o momento crucial da inflexão do eugenismo português no sentido do colonialismo (Gago, 2009: 68-70) e Vítor Fontes, 
presidente da Comissão de Antropologia da Sociedade de Geografia de Lisboa, apelou à formação do pessoal médico e administrativo para a recolha de materiais para pesquisa, enquanto que Mendes Correia apela ao desenvolvimento da investigação científica nas colónias, em especial da antropologia. Paralelamente, foi organizada a Exposição Colonial Portuguesa, aberta de 16 de Junho a 30 de Setembro de 1934, mediante a qual o nosso país deu o seu específico contributo para a tradição dos chamados "zoos humanos" que se vulgarizaram desde o século XIX, prova provada de que, como bem nota Étienne Samain, o ambiente da época era tão positivista quanto exibicionista e etnocêntrico. Este fenómeno resulta das primeiras expedições científicas ao continente africano, quando aos exploradores eram pedidas "amostras" do mais fino exotismo africano, primeiro sob a forma indicial de desenhos, fotografias ou moldagens em gesso, depois, na voragem de visibilidade tão cara ao tempo, sob a forma material do vivo. Diz Samain: "Parece, todavia, que no final do século esses índices não eram suficientemente eloquentes. Queria-se mais. Precisava-se aproximar o selvagem do civilizado: vê-lo, enfim, a olho nu, de carne e osso, e oferecê-lo em espetáculo público" (Samain, 2001: 111-112). Foi nessa condição que se celebrizaram Saartjie Baartman, a chamada Vénus Hotentote, ou, já no século XX, o pigmeu congolês Ota Benga, cujas características físicas ditavam a sua classificação como aberrações e cuja exibição, na linha dos freak shows em voga durante aquele período, se destinava, grosso modo, a vincar a diferença entre o normal e o anormal, no contexto de relações de poder normalizantes no interior das quais a figura do monstro detém um papel fundamental tanto no reforço das normas existentes como na produção de novas normas, patentes estas na produção de conhecimento, de instituições ou de funções estatais (Taylor, 2014: 28; Foucault, 1999). Pelos anos de 1930, contudo, os zoos humanos já eram alvo de indignada contestação por parte de quantos apercebiam, sob o verniz da retórica científica, uma aberrante afinidade com os "espetáculos de monstros", que, no caso português, ainda concitavam o voyeurismo de um público basbaque que nos anos setenta acorria às feiras onde era exibido Gabriel Mondlane, o "gigante de Manjacaze". O verdadeiro mostruário público de mais de trezentos espécimes das raças indígenas coloniais serviu também, e teve por justificação científica como tal louvada por Mendes Correia, o estudo antropobiológico, em condições "laboratoriais", por investigadores dos Institutos de Antropologia da Faculdade de Ciências e do Instituto de Anatomia da Faculdade de Medicina da Universidade do Porto:

Com esse 'material humano' à disposição foram realizadas várias observações antropológicas (...). Alguns desses estudos foram também editados em trabalhos sobre a exposição. Contudo, para além da predominância dos estudos de antropologia física, verifica-se que esses indivíduos foram tomados como representativos dos elementos do grupo 
de onde vinham e a partir do seu estudo foram feitas generalizações relativamente a grupos maiores (Matos, 2012: 229).

E, em nota, acrescenta muito esclarecedoramente Patrícia Ferraz de Matos:

Um dos métodos utilizados nas observações do IAUP foi o método de Giacinto Viola que tinha em vista determinar as dimensões comparadas do tronco e dos membros dos indivíduos. A medição era obtida num aparelho designado 'antropómetro de balança', no qual o indivíduo era deitado, e permitia distinguir dois tipos humanos: o 'brevilíneo' e o 'longilíneo'. A inventariação da suposta diversidade biológica em 'tipos' tinha também como objectivo averiguar as capacidades físicas, mentais e psicológicas que eram consideradas estar associadas a cada um desses 'tipos'. Conhecendo melhor essas capacidades podiam controlar-se melhor os indivíduos que estavam sob a administração colonial e destinarIhes o trabalho, ou as tarefas, mais adequados (Matos, 2012: 229, nota).

Efetivamente, uma das razões que nos ajudam a compreender a priorização da antropobiologia na política colonial diz respeito à sua íntima ligação à racionalização da exploração da mão-de-obra colonial. Como explica ainda Matos, a antropologia física é indispensável por através dela ser possível aferir tanto as características somáticas como as possibilidades psicofísicas dos indivíduos. Daí que, num plano de estudos antropológicos para seis anos elaborado por Mendes Correia em 1941, seja sublinhado o duplo aspecto da tarefa: um intuito puramente científico, por um lado, mas também um intuito de utilidade prática, visando, segundo Mendes Correia, tanto a melhoria das condições de vida dos indígenas quanto, na mesma linha, a sua "colaboração na prosperidade do nosso Império" (Matos, 2012: 234).

Por sua vez, o Congresso Nacional de Ciências da População, em 1940, pode ser considerado como o momento que marca o pleno estabelecimento do que quer que possa ter sido uma comunidade eugenista portuguesa:

O Congresso de Ciências da População foi, no fundo, um palco privilegiado para a discussão da higiene do povo português, assunto que estava então na ordem do dia entre os académicos portugueses. Os textos produzidos estavam imbuídos de termos como 'seleção natural', 'detritos sociais', 'hereditariedade' e até 'eugenia', inserindo-se perfeitamente nas discussões que se desenvolviam nas arenas científicas internacionais. Procuravam demonstrar a pureza do povo português, enquanto condição sine qua non para a sua sobrevivência, aliando os fatores físicos aos morais e até aos ideológicos, considerando mesmo que os seus trabalhos deveriam constituir o fundamento para as reformas sociais que o Estado encetaria, de forma a garantir o futuro da nação e evitar, assim, a sua decadência. Não eram defendidas, no entanto, medidas radicais como as que vingavam na Alemanha nacional-socialista, entre as quais se contavam o aborto eugénico ou a própria eutanásia estatal. A questão da eutanásia e do aborto eram, sem dúvida, assuntos melindrosos, numa sociedade conservadora e católica como a portuguesa, onde a imprensa 
católica denunciava e criticava os 'excessos' praticados na Alemanha. A maioria dos intervenientes portugueses estava longe dos excessos neomalthusianos e dos radicalismos eugénicos, como lhes chamou Mendes Correia. Mesmo assim, sentimentos racistas atravessavam as intervenções de todos estes académicos, sobretudo quando se referiam aos povos colonizados, africanos e indianos, ou judeus e mouros, considerados povos 'invasores', que contrapunham a romanos e germanos, entendidos como a 'nata' da pureza biológica (Pimentel e Ninhos, 2013: 227-228)

Eis constituídos os dois propósitos maiores da investigação antropobiológica nas colónias portuguesa: a avaliação ergométrica - da capacidade de trabalho - e a avaliação étnico-cultural, das caraterísticas comportamentais (designadamente as aptidões intelectivas). Eram indispensáveis para o aproveitamento do autêntico "material humano" (a mesma infelicíssima expressão muito significativamente utilizada por essa mesma época por Heinrich Himmler para se referir aos detidos nos campos de concentração nazis, remetendo-nos ao mesmo tempo para a Gestell heideggeriana enquanto matéria-prima à disposição para indefinida transformação), constituído pelos corpos colonizados ao serviço da ocupação e da exploração colonial. Tratava-se de uma forma de "usos do corpo", na muito produtiva expressão forjada por Giorgio Agamben (Agamben, 2016: 1093 e segs.) que consistia essencialmente no recurso à serviçalidade dos corpos como mão-de-obra maioritariamente desqualificada para o trabalho braçal na agricultura e na indústria colonial, por um lado, e, por outro lado, nas tarefas menores e hierarquicamente inferiores da administração colonial, a serem desempenhadas por setores muito minoritários das etnias suscetíveis de serem assimiláveis e parcialmente civilizadas, isto é, aportuguesadas. Em 1940, ano em tudo e por tudo simbólico - oitavo centenário da fundação da nacionalidade e terceiro centenário da restauração da independência - a antropobiologia dava o seu contributo fundamental para a nacionalização integral da empresa colonial que, de missão histórica secular constitutiva da nação lusa, se volvia doravante em incumbência ingente da preservação da identidade e da existência independente e orgulhosamente solitária num mundo em que esse tipo de ratio fundadora era cada vez mais desafiado pela crítica e pelos factos. Com efeito, em 1940, começava-se a aventar que a mestiçagem podia até ser algo de desejável do ponto de vista das necessidades de uma efetiva colonização, obrigando a antropobiologia portuguesa a distanciar-se da sua matriz originária norte-europeia e do brutal e genocidário racismo germânico que já se encontrava in nuce na obra Die Rehoboter Bastards und das Bastardierungproblem beim Menschen de Eugen Fischer que selou o destino trágico dos bosquímanos da Namíbia, expulsos para zonas desérticas onde a sobrevivência era impossível. A partir de 1945, a mestiçagem vai-se reformulando progressivamente através do filtro lusotropicalista que pretendia restituir à 
nação portuguesa a inocência e a bondade matriciais de um destino paternalista excecional que mais não tinha feito do que "dar novos mundos ao mundo", e só pretendia ser deixado em paz para poder continuar a fazê-lo.

Longe de constituir uma rutura de paradigma, o que houve foi uma "evolução na continuidade" na qual Mendes Correia desempenhou um papel crucial:

Nos anos 50 o autor vai aprimorando a sua visão, motivado também pela mudança do contexto internacional e pelas críticas à presença portuguesa nas colónias. Passa então a considerar o mestiçamento como um agente poderoso na expansão portuguesa (...). Contudo, no que ao contexto colonial dizia respeito não teve inicialmente essa opinião e alertou para os potenciais perigos da mestiçagem ocorrida nas colónias, que deveria ser limitada a circunstâncias especiais, nomeadamente as que estivessem relacionadas com a presença portuguesa efectiva nesses locais. Já numa fase posterior, durante a qual as pressões anticoloniais se difundiram, 0 autor enaltece as capacidades especiais dos portugueses para 0 mestiçamento, que constituía, inclusivamente, um agente na colonização (Matos, 2012: 174)

\section{As missões de investigação colonial e a evolução cosmética da antropobiologia portuguesa}

O pós-Segunda Guerra Mundial veio ditar uma segunda fase na política colonial do Estado Novo, marcada a primeira dessas fases pelo racionamento e congelamento do desenvolvimento das colónias (Margarido, 1975; Pereira, 1987). Nessa época, descrita por Rui Pereira em termos muito coerentes com os propósitos antropobiologistas, "exceptuando-se as descrições, mais ou menos etnográficas, de alguns agentes da colonização, o discurso antropológico possível tinha regredido ao seu ponto mais obscuro, comprazendo-se na exposição da barbárie e da selvageria” (Pereira, 1987, 94). Como explica o mesmo investigador, a antropometria dominava as missões antropológicas, de acordo com a tendência europeia no sentido de mensurar e classificar os tipos raciais, visando afirmar diferenças biológicas que pudessem elas próprias justificar a dominação branca (Matos, 2012: 241; Pereira, 1987: 94).

O cenário internacional posterior a 1945 é, como é sabido, marcado tanto pela irrupção dos movimentos nacionalistas africanos como pela pressão externa no sentido da descolonização. Tanto a nova Constituição de 1951, reformulando o Acto Colonial de 1930 com alterações linguísticas no sentido de depurar o léxico colonialista, recorrendo agora a designações como "províncias" ou "ultramar", como a Lei Orgânica do Ultramar Português, de 1953, reformulando a estrutura administrativa das possessões ultramarinas fazem parte daquilo a que Pereira chama "uma operação de "cosmética»" em dois tempos, com o fito de salvaguardar o poderio colonial, promovendo ao mesmo 
tempo o assimilacionismo, mormente a "assimilação cultural e espiritual" estipulada na Constituição, a qual mais não é do que a replicação da subjugação social, política e económica (Pereira, 1987: 96-97).

Em tal contexto surgem, na década de 50, os trabalhos de campo da equipa de Jorge Dias em Moçambique. Aparentemente descentrados dos objectivos antropobiologistas, o seu pendor etnográfico tende a ser lido como uma rutura que, no entender de autores como Pereira, deve ser denunciada como tendo um fito preventivo: "já não era mais possível encarar os Africanos como uma massa amorfa de trabalhadores braçais ou bons selvagens que havia que saber explorar. Conhecer-lhes as motivações, as práticas e as aspirações, era poder tentar preservá-los do «desassossego»" (Pereira, 1987: 99), palavra outra, esta última, para o potencial de resistência dos povos subjugados.

É este engajamento político da antropologia portuguesa pelo menos até ao 25 de Abril de 1974 que levava Alfredo Margarido a concluir com pessimismo: "Decerto, houve e continua a haver uma produção antropológica, mas esta não é senão a tentativa colonialista de deslocar para um terreno cultural, por assim dizer, problemas exclusivamente políticos. É preciso talvez concluir que a antropologia portuguesa morreu" (Margarido, 1974: 344).

Embora não seja um pioneiro absoluto da antropologia colonial, pois ele próprio reconhecia em Fonseca Cardoso o fundador da disciplina desde as observações antropológicas que realizou na Índia em 1895, foi Mendes Correia o principal responsável pela sistematização que lançou as bases das missões antropológicas às colónias africanas e a Timor de que resultou um vasto e valioso espólio fotográfico:

foi criada a primeira das missões, destinada a Moçambique, pelo Decretolei n.․ 26.842, de 28.7.1936, que teve seis campanhas em 1936, 19371938, 1945, 1946, 1948 e 1955-56, todas chefiadas por Santos Júnior colaborador do IAUP, bolseiro do IAC e da JMGIC, e orientando de Mendes Correia - e alargou-se por quase todo o território. Além desta missão, foram realizadas: uma outra à Guiné, chefiada por Amílcar de Magalhães Mateus, com campanhas em 1945, 1946 e 1947; outra ainda a Angola, chefiada por António de Almeida com campanhas em 1948, 1950, 1952 e 1955; e, por último, a Timor, também chefiada por António de Almeida, com campanhas em 1953, 1954, 1957, 1963, 1964, 1968, 1969, 1974 e 1975 (Matos, 2012: 234).

Geminadas com o levantamento e descrição dos recursos naturais, flora, fauna, minérios, culturas agrícolas, as missões antropológicas registavam as características bio-étnicas das populações, a robustez e a vitalidade dos indivíduos, as suas perspetivas de desenvolvimento e progresso, os costumes dos grupos étnicos, as qualidades psíquicas, as capacidades e tendências (impulsividade, moralidade sugestibilidade, autocontrole, resolução ou decisão, previdência, tenacidade, 
inteligência global e educabilidade), especialmente em vista da sua utilização como força de trabalho, isto é, da sua valia ergométrica. Como diria o próprio Mendes Correia, tratava-se da inventariação integral do fator humano do ponto de vista do seu inestimável interesse que era tanto científico como económico e nacional. Medir as caraterísticas físicas com o objetivo de aquilatar a capacidade de trabalho que o indivíduo seria capaz de prestar, e isto também em função do treino que seria possível ministrar-Ihe em função das suas aptidões psicotécnicas, mais não servia, evidentemente, do que o seu aproveitamento como recurso disponível no âmbito da exploração colonial. O que se pode dizer é que, longe de se ter deparado com uma seca, fera e estéril terra nullius, inútil e despida, calva, informe e da natureza em tudo aborrecida, o que se ofereceu à colonização portuguesa foi uma paisagem luxuriante povoada de recursos imediatamente percebidos como mão-de-obra disponível, desde logo mercadejável como quaisquer outro bem através do tráfico de escravos, para depois continuar a ser explorada servilmente ao abrigo do estatuto do indigenato ${ }^{7}$.

Como bem mostrou Agamben, o material humano manteve através das alterações do estatuto da sua serviçalidade - de usos do corpo colonizado - a qualidade de instrumento animado que mediava a relação do colonizador com a natureza, uma paisagem pletórica de riquezas e com o benefício adicional de se encontrar povoado de recursos para a trabalhar, assim perfazendo a disponibilidade "obediencial" ilimitada do instrumento à intenção do agente principal (Agamben, 2016: 1141). É nesse sentido que, em tudo e por tudo, laboram as missões antropológicas às colónias portuguesas. À mensuração quantificadora, toda inteira assente na «falsa medida do homem» bem descrita por Stephen Jay Gould (1999), que visava traduzir-se metodologicamente em dados estatísticos e demográficos tão exaustivos quanto possível, correspondia, por sua vez, o registo fotográfico de todas as caraterísticas observadas, na melhor tradição do paradigma científico positivista. Eis porque, para além dos vastos espólios arqueológicos, etnográficos e documentais das campanhas realizadas pelas diferentes missões às colónias, encontramos espólios iconográficos (filmes e fotografias) que, além de registarem tudo o anterior, se concentraram na imagem antropobiológica que,

\footnotetext{
${ }^{7}$ O Estatuto dos Indígenas Portugueses das Províncias da Guiné, Angola e Moçambique, foi aprovado por Decreto-lei de 20 de Maio de 1954, no intuito de promover a assimilação das populações nativas das colónias e foi abolido em 1961 por Adriano Moreira, então Ministro do Ultramar, com o objetivo de permitir aos indígenas um acesso mais fácil e abrangente à cidadania portuguesa, já sob pressão das guerras coloniais nos seus primórdios. Esta última versão do estatuto do indigenato sucedeu a uma sequência de instrumentos formais que começaram com Estatuto Político, Social e Criminal dos Indígenas de Angola e Moçambique, de 1926, a que se seguiram o Acto Colonial, de 1930, e a Carta Orgânica do Império Colonial Português e Reforma Administrativa Ultramarina, de 1933.
} 
muito mais do que constituir um documento segundo, tinha um valor científico próprio e intrínseco, na medida em que visibiliza a correlação antropométrica entre as aptidões e os valores e medidas corporais (cor da pele, cabelo, forma das orelhas, do nariz e dos lábios, espessura da massa adiposa, massa muscular, etc.). Pormenor nada negligenciável, as missões serviam também, ainda que indiretamente, o incentivo à população da metrópole para emigrar para as colónias, para tanto servindo os estudos médicos da salubridade das condições prevalecentes nas colónias, exemplificadas nomeadamente com recurso ao estudo dos índices de saúde dos filhos dos colonos nascidos e criados em ambiente colonial. O receio acrescido do risco de mestiçagem daí resultante, denunciado por Mendes Correia e por Tamagnini, era inicialmente compensado com a pressão no sentido de ela se confinar sobretudo às zonas de mais difícil fixação da população europeia "leucoderme", antes da viragem final para uma "democracia racial" lusotropicalista no pós-Segunda Guerra Mundial, quando a mestiçagem se desproblematiza no plano doutrinário e político.

A fotografia antropométrica filia-se na linhagem de valorização científica da técnica fotográfica como reprodução fidedigna da verdade factual, capaz de restituir o real de forma transparente, superior ao discurso, dado que se acreditava que ela era desprovida da retórica deformadora deste. Deste modo investida da crença na sua omnisciência, "(u)ma fotografia é frequentemente percebida como uma cópia não mediada do mundo real, uma película de realidade retirada à própria superfície da vida. Referimo-nos a este conceito como o mito da verdade fotográfica" (Sturken e Cartwright, 2001:17) ${ }^{8}$. Antes de se transferir para o domínio específico da antropobiologia colonial, a sua justificação científica, a sua metodologia e a sua técnica, os seus procedimentos práticos e os seus propósitos já se encontravam todos definitivamente estabelecidos na ciência racial médica, antropológica, forense que se consolidou na convergência das correntes degeneracionistas de Bénédict Morel (1809-1873) e de Cesare Lombroso (1835-1909) e da técnica de fotografia policial desenvolvida por Alphonse Bertillon (1853-1914). Nesta conformidade, a degenerescência transparecia nos estigmas físicos e comportamentais que visivelmente a indiciavam e que a fotografia era capaz de registar com um rigor superior ao do olho humano porque estaria livre das limitações orgânicas deste:

Entre os estigmas físicos, contavam-se a protuberância occipital, as órbitas volumosas, a testa fugidia, as arcadas supraciliares e zigomáticas salientes, as orelhas grandes e afastadas, o nariz tortuoso, os lábios grossos, o prognatismo mandibular, as arcadas dentárias deformadas, os braços excessivamente longos, as mãos grandes, as anomalias dos

\footnotetext{
${ }^{8}$ No original: "A photograph is often perceived to be na unmediated copy of the real world, a trace of reality skimmed off the very surface of life. We refer to this concept as the myth of photographic truth".
} 
órgãos sexuais e a polidactilia. No que respeita aos estigmas anímicos, avultavam a insensibilidade à dor, a ausência de senso moral, a crueldade, o cinismo, a vaidade, o carácter impulsivo, a preguiça excessiva e a tendência para as tatuagens (Santos, 2010: 142)

\section{Nota conclusiva}

A fotografia dos estigmas constituía-se como uma indiciologia dos sintomas de algum modo patológicos, desviantes, degenerativos, regressivos ou atávicos que cindiam uma raça modelar no seu próprio seio entre normais e anormais e, por sua vez, que diferenciava essa raça das demais que não tinham atingido o seu grau de apuramento racial na escala evolutiva da espécie Homo. Tudo o anterior, encontrado em criminosos, prostitutas, homossexuais, doentes mentais, alcoólicos e toxicodependentes, etc., era de igual modo detetável no plano racial e era isso que, justamente, permitia diferenciar com rigor, e logicamente hierarquizar, as diferenças entre raças segundo uma escala de aproximação (o grau de melanodermia, a coloração escura da pele) versus afastamento (as caraterísticas "atávicas", "simiescas") do arquétipo racial. No entanto, ao passo que a higiene racial germânica se ateve sempre a esta matriz biologista e a refinou no sentido da sua arianização, a ciência antropobiológica sul-europeia, latina e portuguesa, atenuou-a e, por assim dizer, "culturalizou-a" no sentido do racismo colonialista precisamente à medida em que ela prosperava com o nazismo num sentido brutalmente eugenista e genocidário. Eis porque 0 jargão obviamente racista e eugenista se encontra praticamente ausente dos espólios e da literatura das missões de investigação colonial portuguesa, dissimulando por essa via os fundamentos teóricos e as metodologias. A historiografia contemporânea não deve pois ser amnésica relativamente à pudenda origo destes porquanto eles se mantiveram, com efeito, no que era essencial, com a sua adaptação à ocupação colonial, para o que era necessária uma avaliação antropométrica da assimilabilidade das etnias colonizadas, e à exploração colonial de mão-de-obra, para o que se impunha uma avaliação bioergográfica das suas aptidões físicas. Foi igualmente por esta via que se deram os efeitos culturais desse paradigma racista, a alterização e a exotização do não branco, que acontecia longe de nós e nunca como nós, mas que, por isso mesmo, nos reafirmava naquilo que éramos e nos justificava naquilo que fazíamos com esses outros. Dessa indiciologia é fruto o espólio iconográfico das missões de investigação antropobiológica nas colónias portuguesas. 


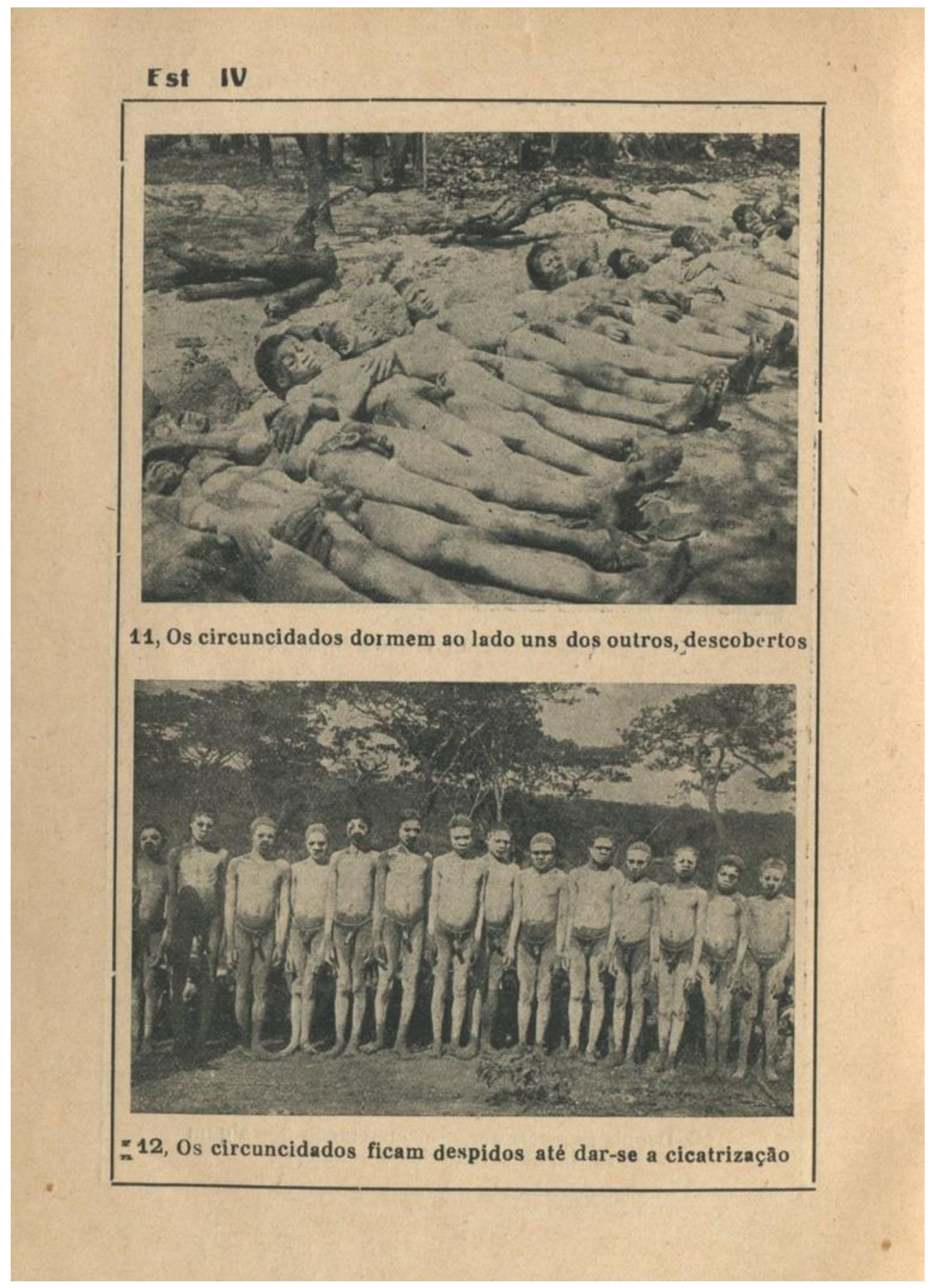

Figura 1. "11. Os circuncidados dormem ao lado uns dos outros, descobertos. 12. Os circuncisados ficam despidos até dar-se a cicatrização." Em Almeida, António (1937). Mutilações étnicas dos aborígenes de Angola. Estampa no IV (s/ paginação). Lisboa: Oficinas Gráficas. 


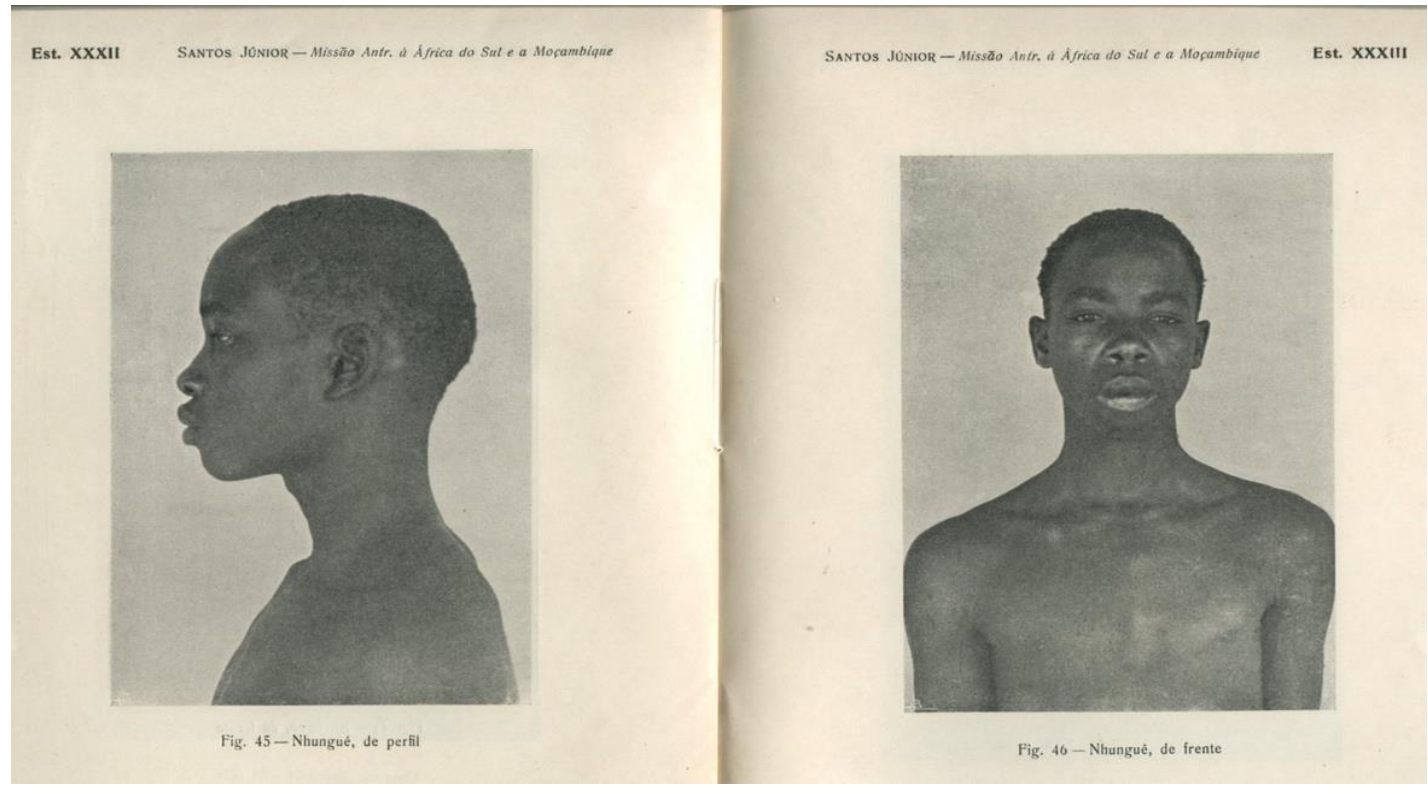

Figura 2. "Fig. 45. Nhungué, de perfil. Fig. 46. Nhungué, de frente". Em Santos Júnior, J.R. (1938). Relatório da Missão Antropológica à África do Sul e Moçambique. $1^{\text {a }}$ Campanha de trabalhos - 1936. Estampas XXXII e XXXIII (s/ paginação). Edição da Sociedade Portuguesa de Antropologia e Etnologia. Porto: Imprensa Portuguesa. 


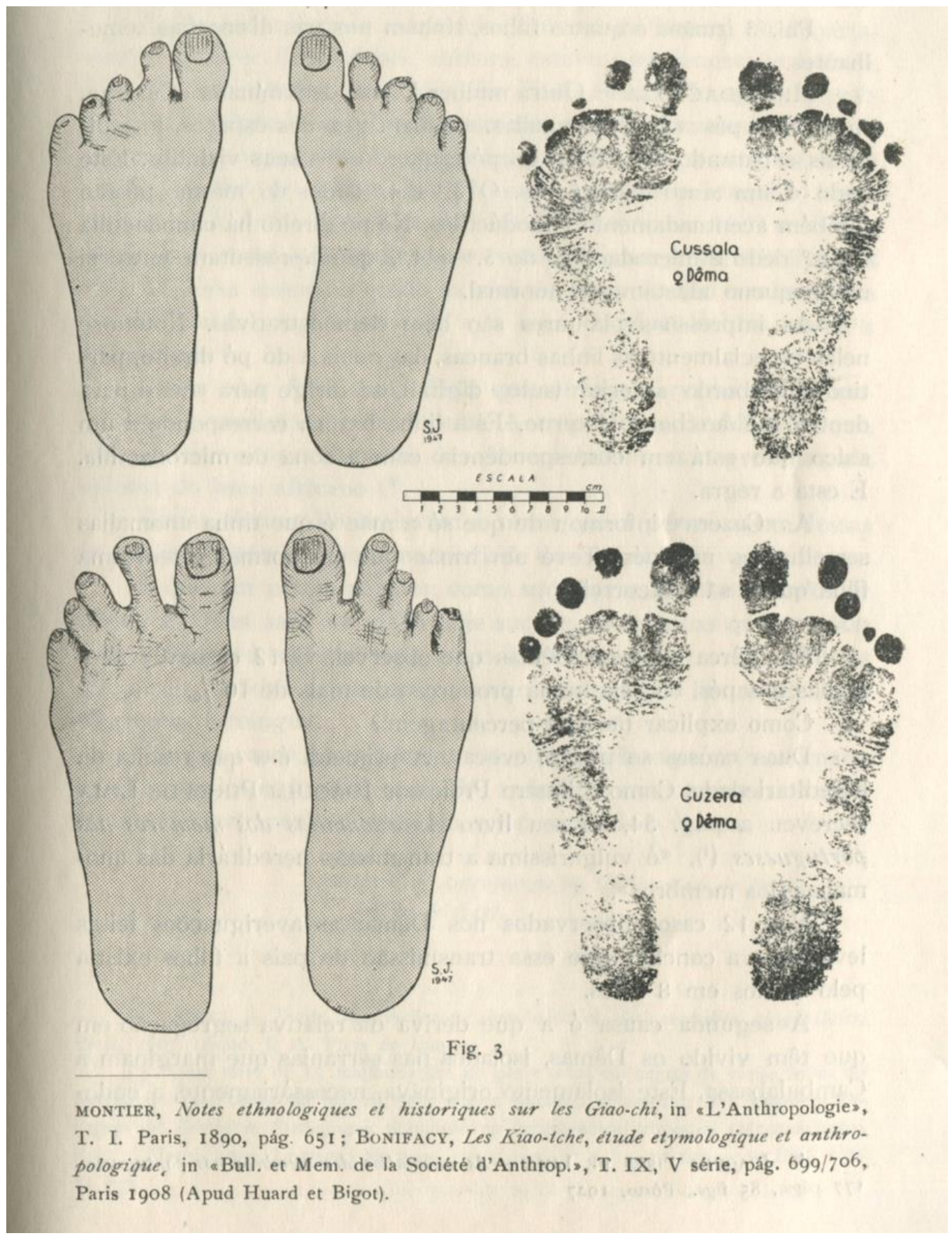

Figura 3. Em Santos Júnior, J.R. (1947) Anomalias pododigitais na tribo dos Dêmas. "Fig. 3 "(s/ paginação). Porto: Tipografia da Enciclopédia Portuguesa. 


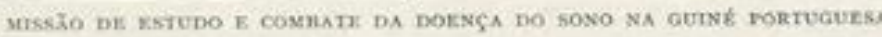

\section{ALGUMA DOCUMENTAÇÃO FOTOGRAFICA DE TRIPANOSSOMADOS}

Apresentada por CRUZ FERREIRA e CARLOS AI MEIDA
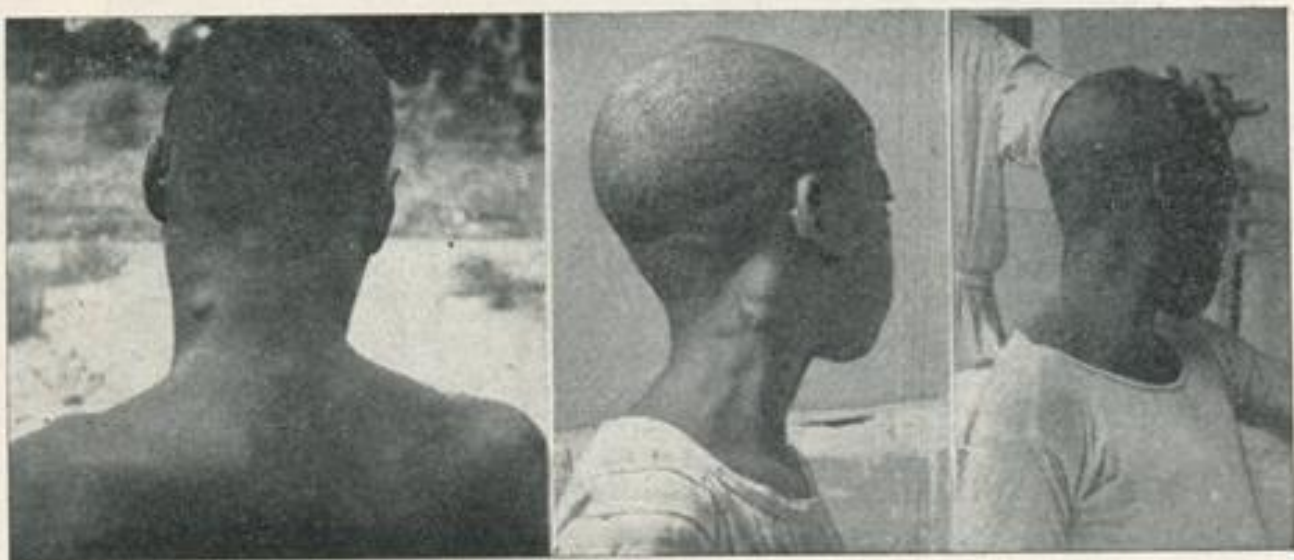

Fig. $x$ - Doente no $3 *$ periodo (L. C. R. $=517$ cel, e $0,64 \%$ afb. $*$ ). Hipertrofia ganglionas $(++)$ Fig. 2 - Doente no periodo lislatico-sanguineo. Hipertrofia ganglionar evidente $(++++)$ Fig. 3 - Doente no 1." periodo. Hipertrotia ganglionar $(t+t+)$
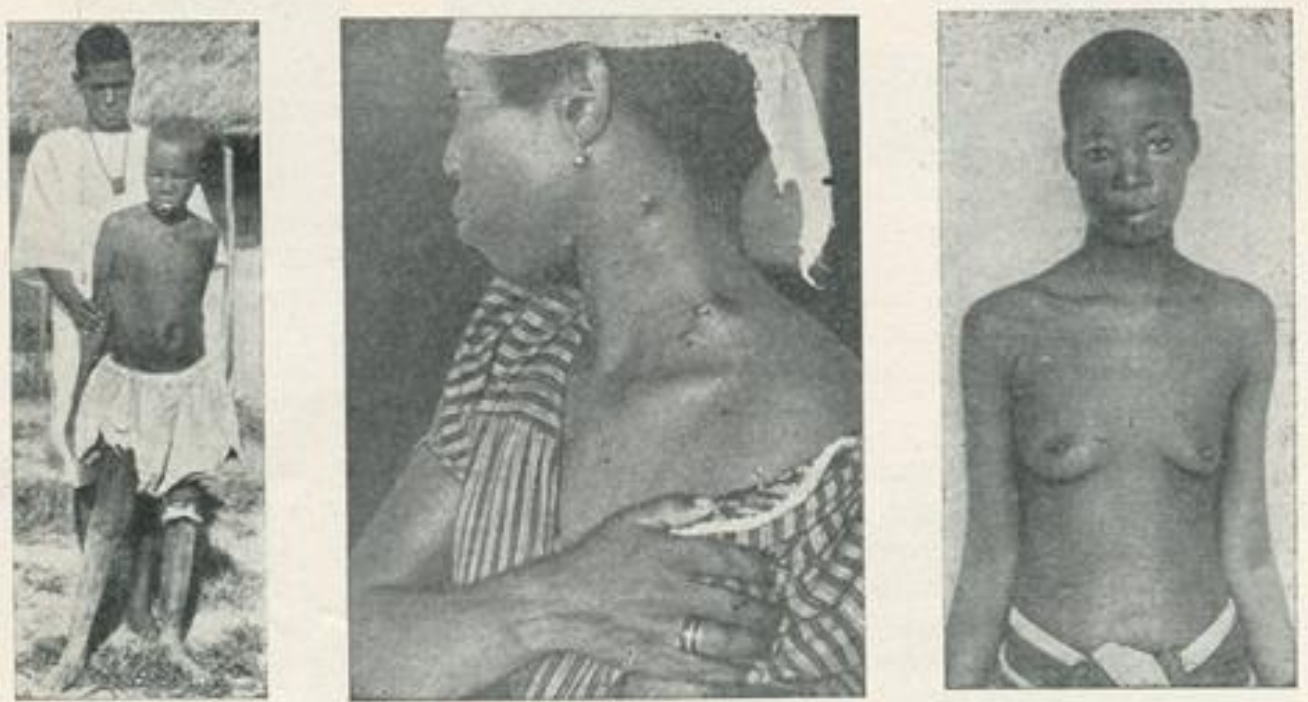

Fif. 4 -Doeste no $3{ }^{\circ}$ periodo (proteinas totais do L. C. $R=0,50 \%$ ) . Coreía. Estado demencial. Edema da fase. Sindroma disenteriforme agudo. Escaras múltiplas. Fig. 5 - Doente no periodo nervoso ja tratada (L. C. R. - cel. - 2) proteinas totais - $-4,4$ ). Queloides de extirpacōes ganglionares anteriores sob es quais se puncionaram glinglios hipertrofiados com tripanossomas. Fig. 6 - Doente em periodo linfático-sasguineo. Edema da face (betn marcado nas palpebras)

Figura 4. Imagens publicadas em Ferreira, Cruz e Almeida, Carlos (1950), "Missão de estudo e combate da doença do sono na Guiné Portuguesa", Gazeta Médica Portuguesa, Vol.III, № 4, 4ํㅡㄴ trimestre, p. 785. 


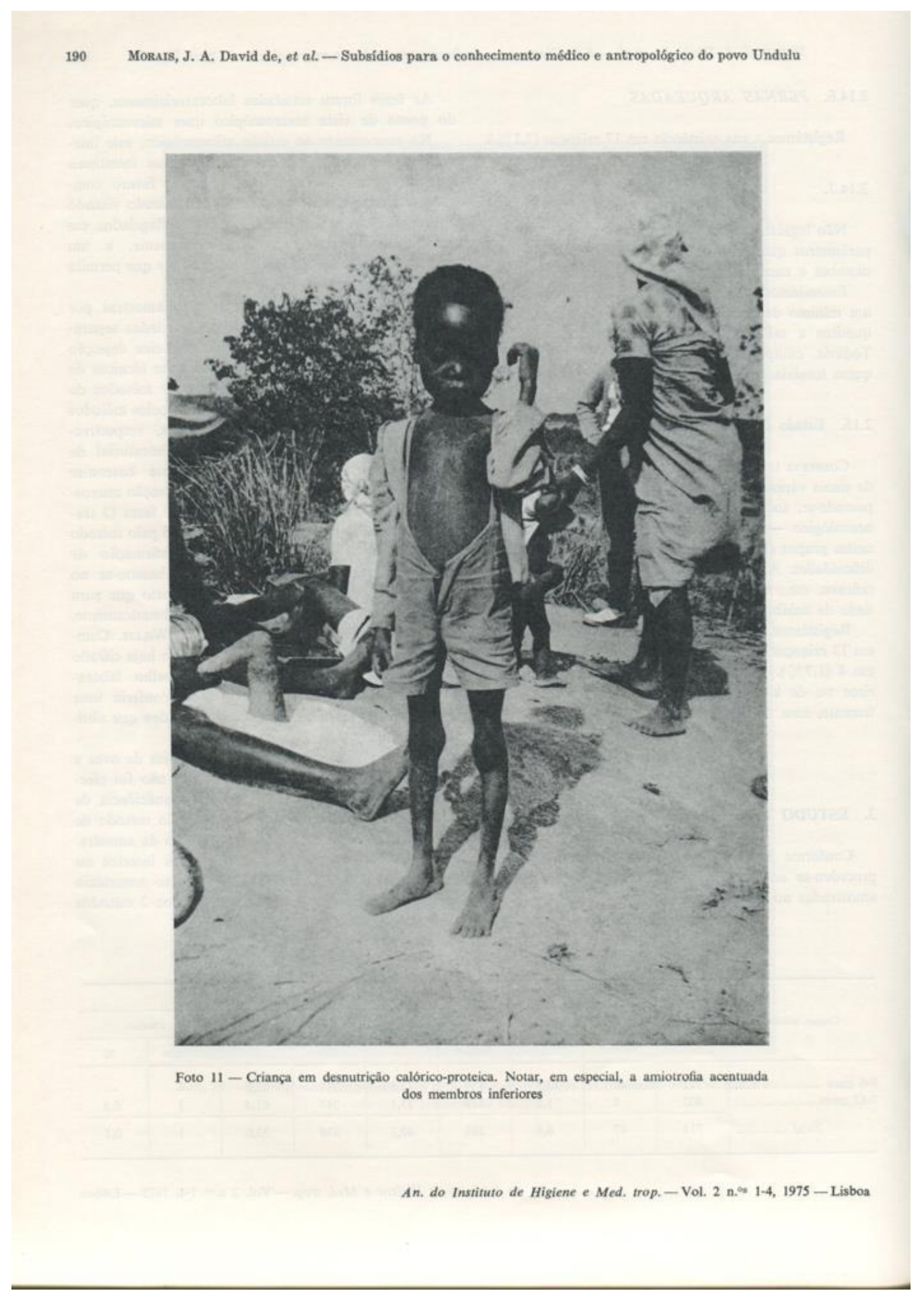

Figura 5. Imagem publicada em Morais, J.A. David (1975) "Subsídios para o conhecimento médico e antropológico do povo Undulu", Anais do Instituto de Higiene e Medicina Tropical, vol.2, nos 1-4, Lisboa. 


\section{Agradecimento}

Artigo elaborado no âmbito do Projeto FCT de I\&D PTDC/COM-OUT/29608/2017: O impulso fotográfico: medindo as colónias e os corpos colonizados. $O$ arquivo fotográfico e fílmico das missões portuguesas de geografia e antropologia

\section{Referências bibliográficas}

Agamben, G. (2016). Homo sacer. L'intégrale 1997-2015. Paris: Seuil

Almeida, A. (1937). Sobre as mutilações étnicas dos aborígenes de Angola. Lisboa: Oficinas Gráficas.

Cascais, A. F. (2014). A receção da eugenia alemã em Portugal 1933-1945, in F. Clara \& C. Ninhos (eds.). A Angústia da Influência. Política, Cultura e Ciência nas relações da Alemanha com a Europa do Sul, 1933-1945 (pp. 157-196). Frankfurt, Berlim, Berna, Bruxelas, Nova lorque, Oxford, Viena: Peter Lang.

Cleminson, R. (2014). Catholicism, Race and Empire: Eugenics in Portugal, 1900-1950. Budapeste e Nova lorque: Central European University Press.

Cleminson, R. (2011). Eugenics in Portugal, 1900-1950: Setting a Research Agenda, East Central Europe, no 38, 133-154.

Correia, A. A. M. (1943). Raças do império. Porto: Portucalense Editora.

Correia, A. A. M. (1933). Sociedade Portuguesa de Estudos Eugénicos, Trabalhos da Sociedade Portuguesa de Antropologia e Etnologia, Vol. VI, Fasc. II, 161.

Foucault, M. (1990/1978). Qu'est-ce que la critique? (Critique et Aufklärung). Bulletin de la Societé Française de Philosophie, no 84, 2, 36-63.

Gago, M. M. (2009). The emergence of genetics in Portugal: J. A. Serra at the crossroads of politics and biological communities (1935-1952). Dissertação de Mestrado, Universidade de Lisboa, Lisboa, Portugal. Consultado em: https://repositorio.ul.pt/handle/10451/4630

Gould, S. J. (2004). A falsa medida do homem. Vila Nova de Famalicão: Quasi.

Heidegger, M. (1958). La question de la technique, In Essais et conférences (pp. 9-48). Paris: Gallimard.

Júnior, S. (1938). Relatório da missão antropológica à África do Sul e a Moçambique, Trabalhos de Antropologia e Etnologia, Vol. VIII, n.ำ 3: 1-52.

Lessa, A. (1938). Federação das sociedades Latinas de Eugénica. Trabalhos da primeira reunião (Textos e comentários), Arquivo de Anatomia e Antropologia, Vol. XIX, 1938, 173-177: 273-292

Madureira, N. L. (2003). A estatística do corpo: Antropologia física e antropometria na alvorada do século XX, Etnográfica, Vol. VII, nº 2: 283-303 
Margarido, A. (1975). Le colonialisme portugais et l'anthropologie, in J. Copans (org.) Anthropologie et Impérialisme (pp. 304-344). Paris: Librairie François Maspero.

Martins, A. C. (2014). Fotografias da missão antropológica e etnológica da Guiné (19461947): entre a forma e o conteúdo, in F. L. Vicente (ed.), O império da visão: Fotografia em contexto colonial (1860-1960) (pp.117-140). Lisboa: Edições 70

Matos, P. C. V. F. (2012). Mendes Correia e a Escola de Antropologia do Porto: Contribuição para o estudo das relações entre antropologia, nacionalismo e colonialismo (de finais de século XIX aos finais da década de 50 do século $X X$ ). Tese de Doutoramento, Universidade de Lisboa, Lisboa, Portugal. Consultado em: https://repositorio.ul.pt/handle/10451/7831

Morais, J. A. et al (1975). Subsídios para o conhecimento médico e antropológico do povo Undulu, Anais do Instituto de Higiene e Medicina Tropical, Vol. 2 (1-4), 43-56.

Pereira, A. L. (2001), Darwin em Portugal [1865-1914]. Filosofia - História - Engenharia Social. Coimbra: Almedina.

Pereira, R. (1987). O desenvolvimento da ciência antropológica na empresa colonial do Estado Novo, in O Estado Novo das Origens ao Fim da Autarcia (1926-1959), vol. II (pp. 89-106). Lisboa: Fragmentos.

Pimentel, I. F. (1998). O aperfeiçoamento da raça, História, Ano XX, nº 3, 18-27.

Pimentel, I. F. e Ninhos, C. (2013). Salazar, Portugal e o Holocausto. Lisboa: Círculo de Leitores.

Proctor, R. (1988). From anthropology to Rassenkund, in G. W. Stocking Jr. (org.), Bones, Bodies, Behaviours (pp.138-179). Madison: University of Wisconsin.

Samain, É. (2001). Quando a fotografia (já) fazia os antropólogos sonharem: O jornal La Lumière (1851-1860). Revista de Antropologia, USP, Vol. 44, n.ำ2, 89-126.

Santos, G. D. (2012). The Birth of Physical Anthropology in Late Imperial Portugal, Current Anthropology, Vol. 53, № S5, S33-S45. doi: 10.1086/662329.

Santos, G. D. (2005). A Escola de Antropologia de Coimbra 1885-1950. Lisboa: Imprensa de Ciências Sociais.

Santos, J. C. (2010). Corpo desviante. Um olhar médico-legal, in AAVV, Corpo: Estado, medicina e sociedade no tempo da I República (pp. 139-149). Lisboa: Imprensa Nacional-Casa da Moeda.

Stocking Jr., G. W. (1988) (ed.). Bones, Bodies, Behaviours. Madison: University of Wisconsin.

Tamagnini, E. \& Serra, J. A. (1942). Subsídios para a história da antropologia portuguesa. Coimbra: $\mathrm{s} / \mathrm{n}$.

Tamagnini, E. (1946). L'Anthropologie au Portugal : conferência efectuada na sede do Royal Anthropological Institute of Great Britain and Ireland em 18 de Abril de 1946. Coimbra: Faculdade de Ciências da Universidade de Coimbra. 
Taylor, D. (2014). Abnormal, in L. Lawlor \& J. Nale (eds.), The Cambridge Foucault Lexicon (pp. 25-35). Nova lorque e Cambridge: Cambridge University Press.

Torgal, L. R. (1999). A universidade e o Estado Novo. O caso de Coimbra 1926-1961. Coimbra: Minerva.

António Fernando Cascais é docente no Departamento de Ciências da Comunicação da Faculdade de Ciências Sociais e Humanas da Universidade NOVA de Lisboa e investigador integrado do ICNOVA. Organizou os livros: Mediações da Ciência - Da Compreensão Pública da Ciência à Mediação dos Saberes - Um Reader (ICNOVA, 2019), Olhares sobre a Cultura Visual da Medicina em Portugal (Unyleya, 2014), Indisciplinar a teoria (Fenda, 2004), A SIDA por um fio (Vega, 1997) e, em colaboração, O vírus-cinema: cinema queer e VIH/sida (Lisboa, 2018), Cinema e Cultura Queer. Queer Lisboa - Festival Internacional de Cinema Queer (Lisboa, 2014), Hospital Miguel Bombarda 1968 - Fotografias de José Fontes (Documenta, 2016), Lei, Segurança, Disciplina. Trinta anos depois de Vigiar e punir de Michel Foucault (CFCUL, 2009), e os nos 38 - "Mediação dos Saberes" (2007), 19 - "Michel Foucault. Uma Analítica da Experiência" (1994) e 33 - “Corpo, Técnica, Subjectividades" (2004) 19 (1994), 33 (2004) and 38 (2007) da Revista de Comunicação e Linguagens. Investigador responsável dos Projectos FCT História da Cultura Visual da Medicina em Portugal e Modelos e Práticas de Comunicação da Ciência em Portugal.

\afcascais1@gmail.com

Mariana Gomes da Costa é investigadora do ICNOVA. Licenciada em Comunicação Social pela Universidade Católica Portuguesa (2005) e em Filosofia pela Faculdade de Letras da Universidade de Lisboa (2010), concluiu em 2018 também na Faculdade de Letras um mestrado sobre a obra de Michel Foucault, com especial enfoque na obra Nascimento da Clínica: Uma Arqueologia do Olhar Médico. Nos últimos anos, conciliou o trabalho de freelancer na área da Imprensa escrita, de revisão de texto e de tradução com a colaboração com os centros de investigação CEFi-UCP e CLEPUL-FLUL, onde desempenhou também tarefas de fixação textual de texto antigo e comunicação institucional. Atualmente, bolseira de doutoramento da Fundação para a Ciência e a Tecnologia, desenvolve um projeto que cruza as áreas das Ciências da Comunicação e da Filosofia para estudar a influência dos dispositivos fotográfico e radiográfico na transformação do olhar médico.

$\bowtie$ mariana.gcosta@gmail.com 